\title{
The whole relationship between environmental variables and firm performance: Competitive advantage and firm resources as mediator variables
}

\author{
María D. López-Gamero*, José F. Molina-Azorín, Enrique Claver-Cortés \\ University of Alicante, San Vicente del Raspeig Campus, P.O. Box. 99, E-03080 Alicante, Spain
}

\section{A R T I C L E I N F O}

\section{Article history:}

Received 20 June 2008

Received in revised form

31 March 2009

Accepted 3 May 2009

Available online $\mathrm{xxx}$

\section{Keywords:}

Early investment

Environmental management

Environmental performance

Firm resources

Competitive advantage

Financial performance

Structural equation model

\begin{abstract}
A B S T R A C T
The examination of the possible direct link between environmental protection and firm performance in the literature has generally produced mixed results. The present paper contributes to the literature by using the resource-based view as a mediating process in this relationship. The study specifically tests whether or not the resource-based view of the firm mediates the positive relationships of proactive environmental management and improved environmental performance with competitive advantage, which also has consequences for financial performance. We also check the possible link between the adoption of a pioneering approach and good environmental management practices. Our findings support that early investment timing and intensity in environmental issues impact on the adoption of a proactive environmental management, which in turn helps to improve environmental performance. The findings also show that a firm's resources and competitive advantage act as mediator variables for a positive relationship between environmental protection and financial performance. This contribution is original because the present paper develops a comprehensive whole picture of this path process, which has previously only been partially discussed in the literature. In addition, this study clarifies a relevant point in the literature, namely that the effect of environmental protection on firm performance is not direct and can vary depending on the sector considered. Whereas competitive advantage in relation to costs influences financial performance in the IPPC law sector, the relevant influence in the hotel sector comes from competitive advantage through differentiation.
\end{abstract}

(c) 2008 Elsevier Ltd. All rights reserved.

\section{Introduction}

Increasing awareness of environmental problems brought about by economic activity has led to greater political and social demands on firms to reduce their environmental impact (Galdeano-Gómez et al., 2008). Managers are confronted with environmental issues. This is not only a question of espousing environmental values, but may have a direct impact on securing sustainable economic success. The ability of organizations to manage their environmental performance is emerging as a strategic issue for firms (Henri and Journeault, 2008). Some authors suggest that environmental management may help organizations to improve their competitiveness (Porter and Van der Linde, 1995; Trung and Kumar, 2005). However, others have questioned the optimism of environmental advocates (Jaffe et al., 1995; Walley and Whitehead, 1994).

The relationship between being proactive in environmental issues and firm performance represents a perplexing issue in the literature.

\footnotetext{
* Corresponding author. Tel./fax: +34 965903606.

E-mail address: md.lopez@ua.es (M.D. López-Gamero).
}

This is because, while some studies have documented a positive relationship (e.g. Aragón-Correa and Rubio-López, 2007; Galdeano-Gómez et al., 2008; Nakao et al., 2007; Wahba, 2008), others do not identify a positive impact of environmental proactivity on financial performance (Link and Naveh, 2006; Wagner, 2005; Watson et al., 2004).

The lack of a solid theoretical foundation repeatedly emerges as the main reason why these empirical studies have not led to knowledge convergence (Aragón-Correa and Sharma, 2003; González-Benito and González-Benito, 2005; Lankoski, 2008; Wagner, 2007). The debate has a number of foci.

Firstly, with regard to environmental variables, some studies use only environmental management variables (González-Benito and González-Benito, 2005; Wahba, 2008), others use only environmental performance variables (Al-Tuwaijri et al., 2004; Wagner, 2005), and a few papers used both environmental management and environmental performance variables jointly (Judge and Douglas, 1998; King and Lenox, 2002; Link and Naveh, 2006). Environmental management and environmental performance are two different concepts that are not automatically linked (Henri and Journeault, 2008). Environmental management encompasses the technical and organizational activities undertaken by the firm for 
the purpose of reducing environmental impacts and minimizing their effects on the natural environment (Cramer, 1998). The output of environmental management is environmental performance (Henri and Journeault, 2008; Klassen and Whybark, 1999). Therefore, we consider that it is necessary to distinguish between environmental management and environmental performance. In fact, the corporate environmental management literature shows that the adoption of environmental practices by organizations typically leads to or favors good environmental performance (Annandale et al., 2004; Melnyk et al., 2003; Zhu and Sarkis, 2004).

Secondly, Christmann (2000), Dowell et al. (2000) and Hart (1995) argue that researchers should investigate green issues through the lens of the resource-based view. Proactive corporate environmental strategies that go beyond regulatory compliance have a positive effect on firm performance when mediated by valuable organizational capabilities (Galdeano-Gómez et al., 2008; Russo and Fouts, 1997; Sharma and Vredenburg, 1998; Wagner, 2005). Moreover, Judge and Elenkov (2005) indicate that the higher the organization's capacity for change, the more likely its environmental performance is to be high. Therefore, we propose to use firm resources as a mediator variable. A proactive attitude on the part of the firm towards the natural environment will probably favor the development of new resources and capabilities, which may in turn may help to achieve competitive advantages (Russo and Fouts, 1997).

Thirdly, the debate also focuses on the concept of 'firm performance'. Some authors believe that this concept involves financial performance measures, and they then focus on the impact of environmental management and/or environmental performance on financial performance (Al-Tuwaijri et al., 2004; Link and Naveh, 2006; Nakao et al., 2007; Wahba, 2008). Other authors use competitive advantage measures to represent firm performance. Christmann (2000) and Shrivastava (1995) examine the potential outcomes of being environmentally proactive, arguing that it contributes to improvements in competitive advantage, by lowering costs and improving differentiation. Following these studies, we propose to analyze the causal relationships between environmental variables and financial performance, considering the role of competitive advantages as mediator variable. For example, a better environmental performance can provide competitive advantage (low cost and differentiation) which will subsequently improve financial performance (Klassen and McLaughlin, 1996; Sharma and Vredenburg, 1998).

Fourthly, some studies have shown that early adopters of environmental technology enjoy a better market and business performance thanks to the early adoption advantage (Gilbert and Birnbaum-More, 1996; Song et al., 1999). The early moving firms may be opting for other more advanced strategies that build on low emissions, but that also involve other sources of sustainable competitive advantage (Ghemawat, 1986). We do not know of any paper that has analyzed the effect of earlier decisions on the link between environmental variables and firm performance; thus, it should be interesting to consider this variable in our study.

Therefore, this paper has at its roots the idea that there is no single, direct relationship between proactive environmental management and firm performance (Aragón-Correa and Sharma, 2003; González-Benito and González-Benito, 2005; Schaltegger and Synnestvedt, 2002; Wagner, 2007). Rather, this relationship seems to depend on environmental management and environmental performance, the firm resources most directly associated with their proactive environmental management, and the effect that proactive environmental management and environmental performance have on competitive advantage and financial performance (Claver et al., 2007). We also test whether or not firms adopting an earlier investment timing and more intense engagement with environmental issues adopt a proactive environmental management.
The paper contributes to the literature in the following ways. As stated above, previous findings in the literature have not been congruent (i.e. positive and negative findings have been found for the same relationships in different papers). These difficulties have arisen because the whole process has not been analyzed as a unit, as we propose to do here. In fact, different papers have highlighted only partial aspects of the whole relationship. For example, some studies have analyzed the relationship between environmental management and environmental performance (Barla, 2007; Szymanski and Tiwari, 2004; Zhu and Sarkis, 2004); other papers have studied the connection between environmental management and financial performance (Melnyk et al., 2003; Menguc and Ozanne, 2005; Wahba, 2008), or between environmental performance and financial performance (Al-Tuwaijri et al., 2004; Nakao et al., 2007; Wagner, 2005; Wagner et al., 2002); and some previous papers have discussed the relationship between firm resources and financial performance (Aragón-Correa and Sharma, 2003; AragónCorrea et al., 2008; Sharma and Vredenburg, 1998). However, these studies have ignored some mediator variables. We propose to consider firm resources and competitive advantages as mediator variables between proactive environmental management and financial performance.

Therefore, our proposal is original in explicitly stating and testing the path process between the different variables in our model. Although this path process is implicit in many previous works (and partially discussed in some theoretical papers), we offer the whole picture. A better understanding of this process helps in understanding the connection between the first and last variables in our models (proactive environmental management and financial performance). These two variables have been analyzed in isolation in many previous works, but that "black box" approach does not promote understanding of the connections and the reasons for potential differences.

In addition, we focus on the importance of firms being early movers in the adoption of proactive environmental management to reduce polluting emissions. This variable may moderate the likelihood that the firm will deploy the resources and capabilities that have a positive effect on firm performance.

This paper has the following structure. Firstly, we offer a literature review followed by a presentation of the research design. Next, we show the findings based on a structural equation model for the hotel sector and for the firms affected by the IPPC law in Spain. Then, we discuss these findings and present some managerial implications. The final section of the paper summarizes the main conclusions.

\section{Environmental protection and firm performance}

\subsection{Early moving and environmental management}

Studies have shown that early adopters in technological and product innovations typically enjoy better market and business performances because of the early adoption advantage (Gilbert and Birnbaum-More, 1996; Song et al., 1999). Hart and Ahuja (1996) demonstrate that the early moving firms may be opting for more advanced environmental strategies that build on low emissions, but which also involve other sources of sustainable competitive advantage (Ghemawat, 1986). For example, firms with very low manufacturing emissions relative to competitors may be able to gain a first-mover advantage in emerging green product markets (Russo and Fouts, 1997). Indeed, attempts to differentiate products as environmentally responsible while continuing to produce comparatively high levels of waste and emissions in production is risky, as outside observers can easily expose this anomaly, destroying the credibility and reputation of the firm (Hart and Ahuja, 1996). Nehrt (1996) conducts a study to investigate investment, and in particular the timing and intensity conditions under 
which financial benefits may result from a firm's investing in pollution-minimizing manufacturing technologies that produce saleable products while reducing pollution. The results show that early investors in pollution-reducing processing equipment benefit from higher profit growth than later investors. This would imply that firms identified as 'earlier and better environmental performers' adopt proactive environmental programs and practices (Sarkis, 2006) and consequently that there is a positive relationship between early investment timing and intensity of involvement in environmental issues and the adoption of proactive environmental practices (Nehrt, 1996; Sarkis, 2006) that involve better firm performance (Ghemawat, 1986; Song et al., 1999). This leads to the formulation of a following proposition:

Hypothesis 1 There is a positive relationship between early investment timing and intensity in environmental issues and the adoption of a proactive environmental management.

\subsection{Environmental protection and firm performance}

\subsubsection{Environmental management and environmental performance}

The environmental management literature has shown that the adoption of environmental practices by firms typically leads to or has to do with good environmental performance (e.g. Annandale et al., 2004; Melnyk et al., 2003; Zhu and Sarkis, 2004).

Better environmental performance levels can derive from different types of environmental practices which do not always have the same effects on environmental performance (Henri and Journeault, 2008). Environmental performance relates to end-ofpipe and pollution proactive environmental management. One would expect an end-of-pipe environmental management to favor improvement, mainly in the undesired outputs of production processes, such as emissions into the air and into the water, which result in few positive effects on environmental performance (Schaltegger and Figge, 2000). By contrast, efficiency improvements brought about by integrating a proactive stance on pollution can encompass activities such as improvements in the firm's energy-use or water-use efficiency, or increased resource efficiency that is, reduced amounts of production input per unit of product output (Wagner, 2005). Therefore, the effect of proactive environmental management on environmental performance should be more positive than that of end-of-pipe activities, although both of them reduce emissions. Moreover, not all these activities have the same impact on firm performance (GonzálezBenito and González-Benito, 2005). In their study, Klassen and Whybark (1999) indicate that pollution proactive technologies exert a positive influence on firm performance, whereas end-ofpipe technologies do not. Wagner (2005) demonstrates that high levels of firm performance coincide with high levels of environmental performance only if the firm's environmental management technology has a pollution proactive orientation. All the above leads to another hypothesis:

Hypothesis 2 A positive relationship exists between proactive environmental management and environmental performance improvement.

\subsubsection{Environmental protection and competitive advantage through the resource-based view}

As we have indicated in the introductory section, along with the main findings described above with regard to the literature about the linkage between environmental variables and financial performance, the impact of environmental variables on financial performance may not be an immediate one. Thus, it is important to analyze the causal relationships between different variables, considering the role of mediating variables. Firm resources and competitive advantage may play an important role.

The contribution of proactive environmental management to competitive advantage is in terms of costs and differentiation (Galdeano-Gómez et al., 2008; González-Benito and GonzálezBenito, 2005; Shrivastava, 1995). Cost advantages typically arise from the adoption of practices that improve the production process (Hart, 1995) increasing its efficiency and reducing input and waste disposal costs (Hart, 1995; Shrivastava, 1995). Decisions such as the purchase of a new green technology, the consideration of greener distribution and transportation systems or the eco-design of products and processes will allow firms to gain competitive advantages derived from cost reductions (Fraj-Andrés et al., 2008). Christmann (2000) provides evidence showing that the higher the firm's level of innovation in pollution proactive technologies, the larger the cost advantage it will gain from environmental strategies. Differentiation advantages typically arise from the perception on the part of customers that the product is more valuable (Lankoski, 2008). Thus, differentiation advantages usually depend on the fit of product characteristics and market needs, and on the firm's ability to market the environmental characteristics of their products and services (Galdeano-Gómez et al., 2008).

In this relationship, firm resources should be considered as a mediator variable. Aragón-Correa and Sharma (2003), Christmann (2000), Sharma and Vredenburg (1998) and Wagner (2005) identify the importance of developing superior firm resources based on the firm's relationship with the natural environment as a source of competitive advantage. For instance, Miles and Covin (2000) indicate that a firm's advantage in reputation is bound to favor a more profitable exploitation of marketing opportunities and, thus, increase market value. Firm resources have been the output of proactive environmental management strategies (e.g. continuous innovation or stakeholder management) and social reputation and legitimization (Aragón-Correa and Rubio-López, 2007). Aragón-Correa et al. (2008) consider that proactive environmental management requires changes in routines and operations and is clearly an organizational competency (Christmann, 2000; Hart, 1995) since it requires the complex coordination of human and technical skills in order to reduce environmental impacts and simultaneously maintain or increase the competitiveness of the firm. Based on the reflections above, we suggest the next two hypotheses:

Hypothesis 3a The firm resources generated through proactive environmental management mediate the positive relationship between proactive environmental management and cost competitive advantage.

Hypothesis $3 \mathrm{~b}$ The firm resources generated through proactive environmental management mediate the positive relationship between proactive environmental management and differentiation competitive advantage.

Other studies have analyzed the relationship between environmental performance and competitive advantage. Wagner and Schaltegger (2004) explain that, for regressions carried out on the subset of firms with an environmental shareholder value-oriented corporate environmental strategy, the reduction of environmental impact has a significant, positive influence on environmental competitiveness dimensions (market-, internally-, profitability- and risk-related environmental competitiveness). Moreover, Hart and Ahuja (1996) point out that less-polluting firms may be more prone to adopt more 
advanced strategies that build on low emissions, but that also involve other sources of sustainable competitive advantage (Ghemawat,1986).

In this relationship, firm resources should be considered as a mediator variable. Environmental performance encourages the development of new firm resources. Konar and Cohen (2001) extend the standard economic technique of decomposing a firm's market value into its tangible and intangible assets, by separating out environmental performance for intangible assets of the firm. Their key finding is that there is a significant positive relationship between environmental performance and the intangible asset value. Moreover, these assets may improve the competitiveness of the firm (López-Gamero et al., 2008). Firms with very low manufacturing emissions with respect to their competitors may be able to gain a first-mover advantage after improving their green image in emerging green product markets (Roy, 1999). Indeed, attempts to differentiate products as environmentally responsible while continuing to produce comparatively high levels of waste and emissions in production is risky, as outside observers can easily expose this anomaly, destroying a firm's credibility and reputation and consequently undermining its current and potential competitiveness (Claver et al., 2007). In the light of the reasons above, we propose the following hypotheses:

Hypothesis 4a The firm resources generated through proactive environmental management mediate the positive relationship between environmental performance improvement and cost competitive advantage.

Hypothesis 4b The firm resources generated through proactive environmental management mediate the positive relationship between environmental performance improvement and differentiation competitive advantage.

\subsubsection{Competitive advantage and financial performance}

Although there are many other variables involved, the ultimate consequence of any competitive advantage deriving from proactive environmental management will most probably be an improvement in financial performance (González-Benito and GonzálezBenito, 2005). Improving their environmental performance allows firms to enhance their competitive edge in terms of reducing costs, gaining a strong reputation among customers and increasing their competitiveness in international markets. These benefits may, in turn, positively impact on the firm's overall financial performance (Lindell and Karagozoglu, 2001). Russo and Fouts (1997) support this argument with a model based on the resource-based view of the firm. They test the idea that improved environmental performance results in a competitive advantage, which in turn leads to financial benefits. Thus, the following hypotheses can be advanced:

Hypothesis 5a Cost competitive advantage has a positive effect on financial performance.

Hypothesis 5b Differentiation competitive advantage has a positive effect on financial performance.

\section{Methodology}

\subsection{Sample and data collection}

To select the sample, we analyzed a selection of firms belonging to the different categories proposed by Hutchinson (1996, p. 15), who provides a classification of different sectors according to the pollution levels caused by each one of them. The assumption was that different sectors generated different levels of environmental impact, from which follows that firms' responses to environmentrelated opportunities and threats would vary as well. Moreover, we considered a number of studies which relate a firm's environmental attitude to the type of activity it develops, which reveal a stronger environmental commitment by firms belonging to sectors with the most serious pollution-related problems (Cairncross, 1992). The least polluting firms, in contrast, suffer less pressure, since the main environmental protection measures revolve around industrial activities causing a direct, visible impact on the environment (Bowen, 2000). Gamble et al. (1995), Gray et al. (2001) and Shih et al. (2006) pointed out that sectors with long-term cumulative pollution problems, including such high-pollution sectors as the oil sector, chemical sector and steel sector, are more likely to take the initiative to disclose environmental information than less-polluting sectors, including the service sector.

In a previous exploratory phase, we also held interviews with managers of firms in different industries. We could observe that the most polluting firms really had to face greater legislative and social pressures. Those pressures produced a higher level of managerial commitment to the environment which favored the development of processes linked to a voluntary norm based on the adoption of a 'proactive' logic, rejecting the importance of the environmental legislation understood from corrective end-of-pipe actions. Therefore, we decided to analyze the model drawing a distinction between two groups of firms: the most and the least polluting firms.

In the most polluting firms, the importance of environmental legislation for managers would make sense when the approach to environmental legislation takes place under the same conditions as in the voluntary normative. In this case, we took as a reference the Law 16/2002 of July 1st about Integrated Pollution Prevention and Control (IPPC). This Directive applies to six industrial categories: energy, production and processing of metals, minerals, chemicals, and 'others', including pulp and paper production, textile treatment, tanning, food processing and intensive livestock operations. The IPPC Directive seeks to avoid or, when that is not possible, to reduce and control pollution in the atmosphere, water or the land, through the establishment of an integrated pollution proactive and control system that has as its aim a high level of protection for the environment as a whole (Art. 1). This environmental legislation therefore includes proactive pollution techniques as an essential part of its development.

To represent the least polluting firms, we selected the service industry, because it has been considered by the literature as one of the less-pollution sectors (Henriques and Sadorsky, 1996; Ramus and Montiel, 2005; Shih et al., 2006). Following Sharma et al. (2007), its impacts are less visible as compared to those of, for example, the chemical and utility industries. Within the service industry, we have analyzed the tourism sector. This sector, specifically the hotel sector, is not one which causes gross environmental pollution nor does it consume vast amounts of non-renewable resources (Chan and Wong, 2006; Kirk, 1995). The tourism sector is a good example of a service industry because of its importance in this sector. For example, the tourism sector was responsible for the generation of $14.71 \%$ of employment in Europe in 2006 (Eurostat, 2009). In Spain it was responsible for the generation of $15.18 \%$ of employment (INE, 2009) and for the generation of $8.67 \%$ of GDP in 2007, both within the service sector (INE, 2009).

Data to test the hypotheses came from a mail survey of the managers of 3900 three, four and five-star hotels ${ }^{1}$ and 4187

\footnotetext{
${ }^{1}$ We are considering as a unit of analysis sites. We decided to take these legal categories as a reference because they are the most dynamic and innovative ones and correspond to hotels which show a wider variety of characteristics and possibilities such as size, chain membership, or the types of tourism they can offer
} 
Spanish firms affected by the IPPC $\operatorname{law}^{2}$ in September 2004. The covering letter and the instructions indicated that the survey respondent should be an environment manager, or, failing that, the firm should forward it to someone familiar with these issues. The interviewee had the option of filling in the questionnaire on a web page if they chose. Four reminder e-mails followed during the four weeks after the initial mailing so as to encourage responses. Furthermore, we made follow-up phone calls starting two weeks later. 240 hotels and 208 firms affected by the IPPC law sent their responses. Considering the length of the questionnaire and the senior level of the managers targeted, the response rate achieved seems acceptable and is in keeping with that obtained by other researchers who have studied similar organizational phenomena in Spain (Brío and Junquera, 2001; Brío et al., 2002; Carmona-Moreno et al., 2004). In order to detect possible problems related to non-response error or bias, we drew a comparison between early respondents and late respondents within each population (Armstrong and Overton, 1977), after which we divided the data obtained into thirds, within each population, according to the number of working days between the initial mailing to the firm and the reception of the questionnaire. The $T$-tests between the first and last third revealed no statistically significant differences $(p<0.05)$ in the mail responses for the constructs used. Hence, on an overall basis, non-response bias does not appear to be a problem in our study.

\subsection{Measurements}

\subsubsection{Early investment timing and intensity in environmental issues}

This variable resulted from the combination of two variables referring to the time (month) during which a firm implements some environmental practice and the type of certification it obtains. The main objective was to identify firms that were pioneers in the adoption of proactive environmental practices. With this aim, we weighted the variable 'time-month' according to whether the firm was not certified (0.2), had a certification in accordance with the ISO 14001 or another type of norm (0.4), had a certification in accordance with the ISO 14001 and another type of norm (0.6), or was verified according to the EMAS Regulation (0.8). We have weighted the last verification to a greater extent because of the greater rigour which firms have to endure in their attempts to achieve it.

\subsubsection{Environmental management}

Due to limited or non-availability of publicly available environmental performance data, a firm's environmental strategy has usually been measured in terms of the self-perception of managers (Aragón-Correa et al., 2008). In our case, we used perception measures because there were no publicly available data on environmental practices in Spain. We considered two groups of items to measure the extent to which firms were proactive in environmental management drawn from different studies (Judge and Douglas, 1998; Klassen and Whybark, 1999; Carmona-Moreno et al., 2004; Melnyk et al., 2003). The first category was related to organizational aspects of environmental management, and the second group was related to technical aspects. We used Likert scales for the operationalization of those constructs. Managers were asked to evaluate on a range of 7-points from 1 (they had not addressed that issue) to 7 (they were leaders on that practice in their sector) if they had adopted those environmental practices. The 'Environmental

\footnotetext{
2 Spain is a part of the EU, and environmental regulations are same in the whole area (and similar to others in the rest of the developed world), which means that our sample has potential for generalization.
}

management - organizational aspects' group was measured using 15 items. Table A1 in Appendix shows the results of standardized varimax rotation of those items resulting in two significant factors (eigenvalues $>1$ ): F1EMORG = organizational aspects linked to knowledge and learning in the development of environmental practices (Cronbach's alpha $=0.93$ (IPPC law); 0.94 (hotels)), and F2EMORG $=$ variables which reflected the connection link between the firm and its stakeholders during the development of the organization's environmental management (Cronbach's alpha $=0.74$ (IPPC law); 0.89 (hotels)). 'Environmental management - technical aspects' was measured using 9 items. Exploratory principal components analysis with varimax rotation of those items showed that they formed only one factor with eigenvalue $>1$ (Cronbach's alpha $=0.86$ (IPPC law); 0.89 (hotels)).

\subsubsection{Environmental performance}

The environmental performance variable included 9 items drawn from Klassen and Whybark (1999), Stanwick and Stanwick (1998) and Wagner et al. (2002). We asked managers to position his or her firm on a scale of 1-7 depending on the position of the firm in relation to competitors in environmental performance issues such as efficient use resources, reduction of emissions, residues and acoustic pollution, and so on. Exploratory principal components analysis with varimax rotation of those items showed that they formed only one factor with eigenvalue $>1$ (Cronbach's alpha $=0.91$ (IPPC law); 0.93 (hotels)).

\subsubsection{New firm resources}

Firms may acquire or develop resources as a result of their environmental practices such as the capability to boost the process of learning in environmental issues, the ability to develop formal and informal environmental information exchange channels and the capability to cooperate with external stakeholders (AragónCorrea and Sharma, 2003; Christmann, 2000; Hart, 1995). We used 7 items based on new resources and capabilities. Managers had to evaluate if those resources had developed in the firm as a consequence of the adoption of proactive environmental management. Each item was measured on a 7-point Likert response scale ( 1 = "strongly disagree", 7 = "strongly agree"). A factor analysis was carried out of those items, resulting in one factor with eigenvalue $>1$, and Cronbach's alpha $=0.88$ (IPPC law); 0.92 (hotels).

\subsubsection{Competitive advantage}

Environmental competitiveness was defined as that part of the overall competitiveness of a firm, which could be influenced by environmental management activities (Wagner and Schaltegger, 2004). We considered two groups of items to measure that variable: competitive advantage on costs ( 4 items) and competitive advantage in differentiation (5 items), which were drawn from Christmann (2000), Karagozoglu and Lindell (2000) and Wagner and Schaltegger (2004). Through a 7-point Likert scale, managers rated his or her organization's competitiveness relative to that of other firms in the sector. A factor analysis was carried out on the data for the items of competitive advantage on costs, resulting in one factor with eigenvalue $>1$, and Cronbach's alpha $=0.82$ (IPPC law); 0.77 (hotels). In relation to the competitive advantage in differentiation, again one factor was found in the factor analysis, with eigenvalue $>1$, and Cronbach's alpha $=0.82$ (IPPC law); 0.86 (hotels).

\subsubsection{Financial performance}

The environmental literature has used subjective perceptions of managers (e.g. Judge and Douglas, 1998; Sharma and Vredenburg, 1998). The main reason is that managers were more open to 


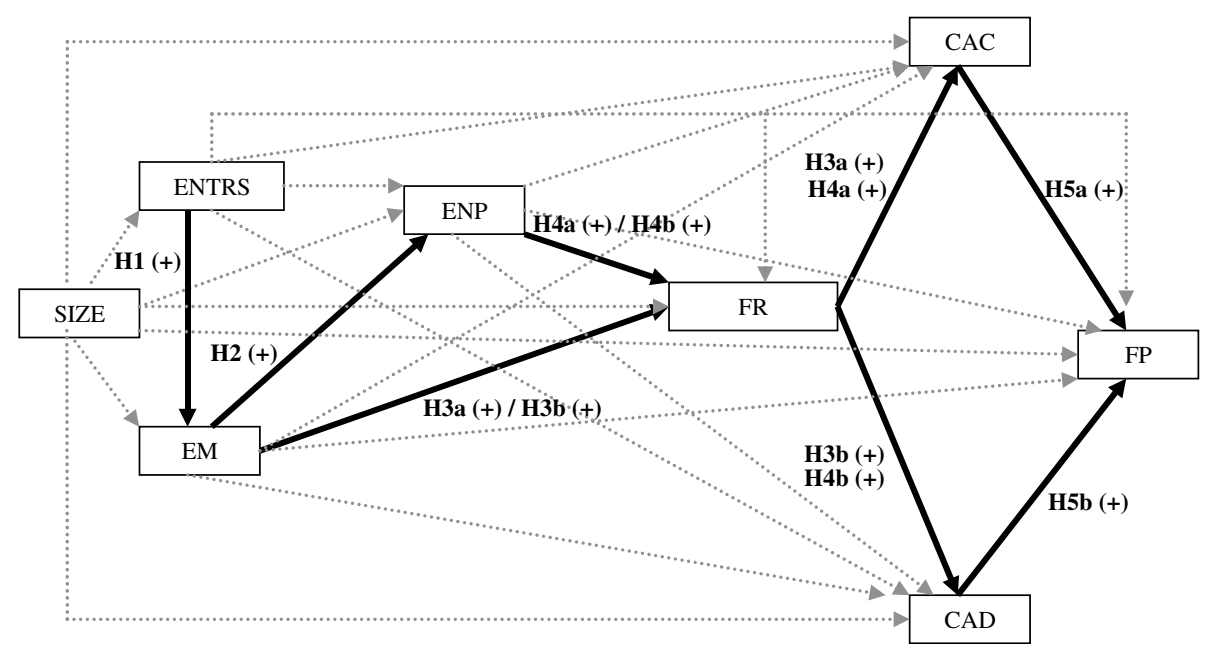

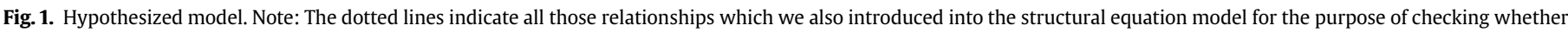

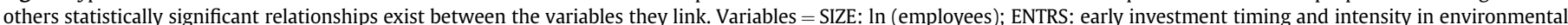

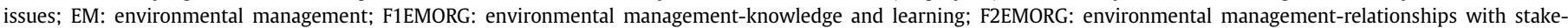

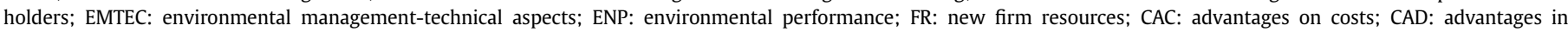
differentiation; FP: financial performance.

offering their perceptions rather than to offering precise quantitative data (Aragón-Correa et al., 2008). We tested the model using a perceptual measure with three items (added value growth, economic and financial profitability) in which, through a 7-point Likert scale, managers rated his or her organization's performance relative to that of other firms in the sector. Exploratory principal components analysis with varimax rotation of those items showed that they formed only one factor with eigenvalue $>1$ (Cronbach's alpha $=0.92$ (IPPC law); 0.87 (hotels)).

\subsubsection{Control variable}

Size was considered as a control variable. The logarithm of a firm's number of employees was used to measure size.

\section{Findings}

We used structural equation modeling (Lisrel 8.5) to examine our hypotheses, using maximum likelihood (ML) with robust estimators (Satorra and Bentler, 1994) as a method to estimate the parameters, since the assumption of multivariate normal distribution was no longer valid and the measurements for some variables were not continuous. Our input matrix while using this method was the asymptotic variance-covariance matrix. We used a recursive non-saturated model, taking size $\left(\xi_{1}\right)$ (control variable) as the exogenous latent variable; and early investment timing and intensity in environmental issues $\left(\eta_{1}\right)$, environmental management $\left(\eta_{2}\right)$, environmental performance $\left(\eta_{3}\right)$ firm resources $\left(\eta_{4}\right)$, competitive advantage on costs $\left(\eta_{5}\right)$, competitive advantage in differentiation $\left(\eta_{6}\right)$, and financial performance $\left(\eta_{7}\right)$ as endogenous latent variables. Through its flexible interplay between theory and data, this structural equation model approach bridges theoretical and empirical knowledge for a better understanding of the real world. Such analysis allows for modeling based on both latent (unobservable) variables and manifest (observable) variables, a property well suited to a hypothesized model where most of the represented constructs are abstractions of unobservable phenomena.

Fig. 1 shows our proposed model and the hypotheses. Table 1 (IPPC law sector) and Table 2 (hotels sector) present the means, standard deviations, reliability coefficients, and correlations among the variables. All composite reliabilities exceeded the recommended 0.7 level and were greater than the correlation between the two constructs of interest. Prior to conducting our analyses, we followed the procedure outlined by Bono and Judge (2003) for examining the measurement properties of our variables to prevent interpretational problems inherent in simultaneous estimation of measurement and structural models (Aragón-Correa et al., 2008).

The process of testing the measurement model is basically a confirmatory factor analysis (CFA) task - based on knowledge of

Table 1

Means, standard deviations, and correlations - IPPC law.

\begin{tabular}{|c|c|c|c|c|c|c|c|c|c|c|c|c|}
\hline & Mean & s.d. & 1 & 2 & 3 & 4 & 5 & 6 & 7 & 8 & 9 & 10 \\
\hline 1. Size & 4.83 & 0.96 & - & & & & & & & & & \\
\hline 2. Early investment timing and intensity in environmental issues & 3.25 & 1.04 & $0.332^{* *}$ & - & & & & & & & & \\
\hline 3. Environmental management-knowledge and learning & 5.94 & 1.06 & $0.271^{* *}$ & $0.599^{* *}$ & 0.938 & & & & & & & \\
\hline 4. Environmental management-relationships with stakeholders & 4.92 & 0.90 & $0.215^{* *}$ & $0.440^{* *}$ & $0.607^{* *}$ & 0.790 & & & & & & \\
\hline 5. Environmental management-technical aspects & 5.55 & 0.93 & $0.237^{* *}$ & $0.486^{* *}$ & $0.637^{* *}$ & $0.601^{* *}$ & 0.868 & & & & & \\
\hline 6. Environmental performance & 5.64 & 1.11 & $0.169^{*}$ & $0.417^{* *}$ & $0.544^{* *}$ & $0.464^{* *}$ & $0.601^{* *}$ & 0.915 & & & & \\
\hline 7. New firm resources & 5.19 & 1.03 & $0.139^{*}$ & $0.359^{* *}$ & $0.526^{* *}$ & $0.489^{* *}$ & $0.464^{* *}$ & $0.445^{* *}$ & 0.714 & & & \\
\hline 8. Competitive advantage on costs & 5.29 & 1.11 & $0.136^{*}$ & $0.327^{* *}$ & $0.522^{* *}$ & $0.506^{* *}$ & $0.489 * *$ & $0.415^{* *}$ & $0.616^{* *}$ & 0.822 & & \\
\hline 9. Competitive advantage in differentiation & 3.48 & 1.08 & $0.188^{* *}$ & $0.429^{* *}$ & $0.528^{* *}$ & $0.468^{* *}$ & $0.506^{* *}$ & $0.524^{* *}$ & $0.482^{* *}$ & $0.439^{* *}$ & 0.831 & \\
\hline 10. Financial performance & 4.80 & 0.95 & $0.170^{*}$ & $0.381^{* *}$ & $0.514^{* *}$ & $0.537^{* *}$ & $0.468^{* *}$ & $0.556^{* *}$ & $0.514^{* *}$ & $0.600^{* *}$ & $0.634^{* *}$ & 0.930 \\
\hline
\end{tabular}

Scale reliabilities (composite reliability) are on the diagonal in boldface.

${ }^{*} p<0.05 ;{ }^{* *} p<0.01$. 
Table 2

Means, standard deviations, and correlations - Hotels.

\begin{tabular}{|c|c|c|c|c|c|c|c|c|c|c|c|c|}
\hline & Mean & s.d. & 1 & 2 & 3 & 4 & 5 & 6 & 7 & 8 & 9 & 10 \\
\hline 1. Early investment timing and intensity in environmental issues & 3.49 & 0.93 & - & & & & & & & & & \\
\hline 2. Size & 2.79 & 0.82 & $0.368^{* *}$ & - & & & & & & & & \\
\hline 3. Environmental management-knowledge and learning & 5.62 & 0.77 & $0.266^{* *}$ & $0.708^{* *}$ & 0.928 & & & & & & & \\
\hline 4. Environmental management-relationships with stakeholders & 4.43 & 0.78 & $0.208^{* *}$ & $0.645^{* *}$ & $0.809^{* *}$ & 0.886 & & & & & & \\
\hline 5. Environmental management-technical aspects & 6.01 & 0.67 & $0.244^{* *}$ & $0.511^{* *}$ & $0.746^{* *}$ & $0.652^{* *}$ & 0.886 & & & & & \\
\hline 6. Environmental performance & 5.67 & 0.70 & $0.134^{*}$ & $0.618^{* *}$ & $0.747^{* *}$ & $0.633^{* *}$ & $0.622^{* *}$ & 0.929 & & & & \\
\hline 7. New firm resources & 4.59 & 0.77 & $0.256^{* *}$ & $0.684^{* *}$ & $0.896^{* *}$ & $0.896^{* *}$ & $0.702^{* *}$ & $0.698^{* *}$ & 0.917 & & & \\
\hline 8. Competitive advantage on costs & 2.93 & 0.72 & 0.124 & 0.016 & 0.041 & 0.121 & $0.149^{*}$ & -0.061 & 0.110 & 0.778 & & \\
\hline 9. Competitive advantage in differentiation & 5.39 & 0.677 & 0.094 & $0.419^{* *}$ & $0.560^{* *}$ & $0.567^{* *}$ & $0.544^{* *}$ & $0.533^{* *}$ & $0.599 * *$ & $0.224^{* *}$ & 0.863 & \\
\hline 10. Financial performance & 3.53 & 0.75 & $0.143^{*}$ & $0.222^{* *}$ & $0.226^{* *}$ & $0.247^{* *}$ & $0.258^{* *}$ & $0.150^{*}$ & $0.263^{* *}$ & $0.521^{* *}$ & $0.333^{* *}$ & 0.723 \\
\hline
\end{tabular}

Scale reliabilities (composite reliability) are on the diagonal in boldface.

${ }^{*} p<0.05 ;{ }^{* *} p<0.01$.

theory and empirical research, the hypothesized relationships between the observed measures and the underlying factors postulated a priori is being statistically tested. CFA was conducted to assess model fit (Jöreskog and Sorbom, 1993), for the measurement model. The fit statistics for the measurement model given in Table 3 indicate that the measurement model fits the data well. Furthermore, the measures of error were uncorrelated, allowing progression to the next stage of the SEM process (further detail of the results can be obtained from the corresponding author).

Seeking to reduce the number of parameters to estimate, we resorted to the formation of compound variables, so that a single indicator resulting from the sum of them all could determine each factor (Gribbons and Hocevar, 1998; Landis et al., 2000).
Environmental management was the only variable which was considered through three indicators as a result of three factors (F1EMORG, F2EMORG and EMTEC). Each of these indicators was also resulting from the sum of them all could determine each factor.

Final results of this model, which are displayed in Figs. 2 and 3, revealed that each final item significantly loads on its respective construct showing high convergent validity of the measurement scale for each construct. The hypothesized model provided an acceptable fit to the data (Table 4). The Chi-square was significant $\left(\chi^{2}=27.930, \mathrm{df}=20, p=0.111\right.$ in the hotel sector and $\chi^{2}=21.524, \mathrm{df}=20, p=0.367$ in the group of firms affected by the IPPC law) and fit indices clearly exceeded the preferred 0.90 threshold. All of the modification indices for the beta pathways

Table 3

Fit statistics for the measurement model.

\begin{tabular}{|c|c|c|c|c|c|c|c|c|c|c|}
\hline & & $\chi^{2}$ Satorra-Bentler $(\mathrm{df})$ & RMSEA & 90\% Confidence & GFI & AGFI & NFI & NNFI & CFI & $\mathrm{NC}\left(\chi^{2} / \mathrm{df}\right)$ \\
\hline & & $p$-Value & & interval for RMSEA & & & & & & \\
\hline \multirow[t]{7}{*}{ Hotels } & EMORG & $145.25(76)$ & 0.06 & $(0.046 ; 0.077)$ & 0.89 & 0.85 & 0.92 & 0.94 & 0.95 & 1.91 \\
\hline & EMTEC & $\begin{array}{l}12.11(8) \\
0.146\end{array}$ & 0.046 & $(0.0 ; 0.096)$ & 0.97 & 0.93 & 0.97 & 0.97 & 0.98 & 1.51 \\
\hline & ENP & $\begin{array}{l}4.31(9) \\
0.89\end{array}$ & 0.0 & $(0.0 ; 0.033)$ & 0.99 & 0.97 & 0.99 & 0.99 & 1 & - \\
\hline & FR & $\begin{array}{l}5.26(5) \\
0.385\end{array}$ & 0.0149 & $(0.0 ; 0.0923)$ & 0.985 & 0.956 & 0.989 & 0.99 & 0.99 & 1.05 \\
\hline & $\mathrm{CAC}^{*}$ & $\begin{array}{l}0(1) \\
0\end{array}$ & 0 & - & 1 & 1 & 1 & 1 & 1 & - \\
\hline & CAD & $\begin{array}{l}3.49(2) \\
0.17\end{array}$ & 0.055 & $(0.0 ; 0.152)$ & 0.99 & 0.95 & 0.99 & 0.98 & 0.99 & 1.74 \\
\hline & $\mathrm{FP}^{*}$ & $\begin{array}{l}0(1) \\
0\end{array}$ & 0 & - & 1 & 1 & 1 & 1 & 1 & - \\
\hline \multirow[t]{6}{*}{ IPPC law } & EMORG & $\begin{array}{l}41.26(25) \\
0.021\end{array}$ & 0.056 & $(0.021 ; 0.085)$ & 0.937 & 0.886 & 0.959 & 0.965 & 0.976 & 1.65 \\
\hline & EMTEC & $\begin{array}{l}8.79(5) \\
0.117\end{array}$ & 0.060 & $(0.0 ; 0.125)$ & 0.980 & 0.939 & 0.979 & 0.977 & 0.989 & 1.76 \\
\hline & ENP & $\begin{array}{l}11.02(9) \\
0.274\end{array}$ & 0.032 & $(0.0 ; 0.0888)$ & 0.973 & 0.937 & 0.979 & 0.983 & 0.990 & 1.22 \\
\hline & FR & $\begin{array}{l}7.75(5) \\
0.170\end{array}$ & 0.051 & $(0.0 ; 0.118)$ & 0.979 & 0.937 & 0.980 & 0.978 & 0.989 & 1.55 \\
\hline & $\mathrm{CAC}^{* *}$ & $\begin{array}{l}0(1) \\
0\end{array}$ & 0 & - & 1 & 1 & 1 & 1 & 1 & - \\
\hline & CAD-FP** & $\begin{array}{l}6.73(4) \\
0.150\end{array}$ & 0.057 & $(0.0 ; 0.130)$ & 0.985 & 0.944 & 0.989 & 0.987 & 0.995 & 1.68 \\
\hline
\end{tabular}

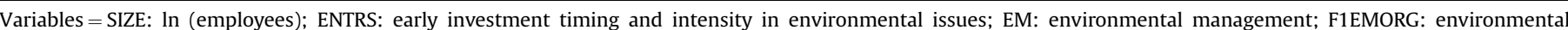

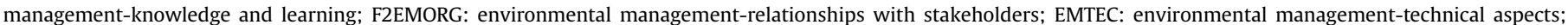
ENP: environmental performance; FR: new firm resources; CAC: advantages on costs; CAD: advantages in differentiation; FP: financial performance.

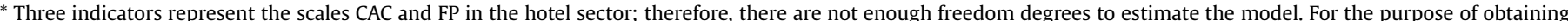

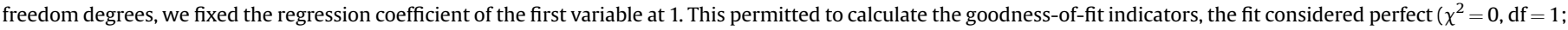
GFI, AGFI, NFI, NNFI, CFI =1; RMSEA =0). The same happens with the scale CAC in the IPPC law sector.

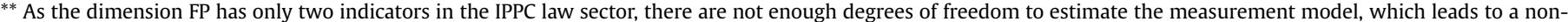

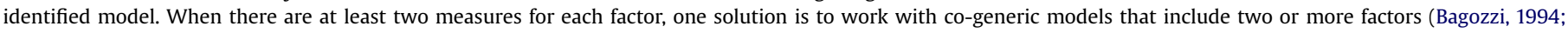
Jöreskog, 1971). This is why we decided to use a joint model (CAD/FP) which reflects the correlation between these two factors. 


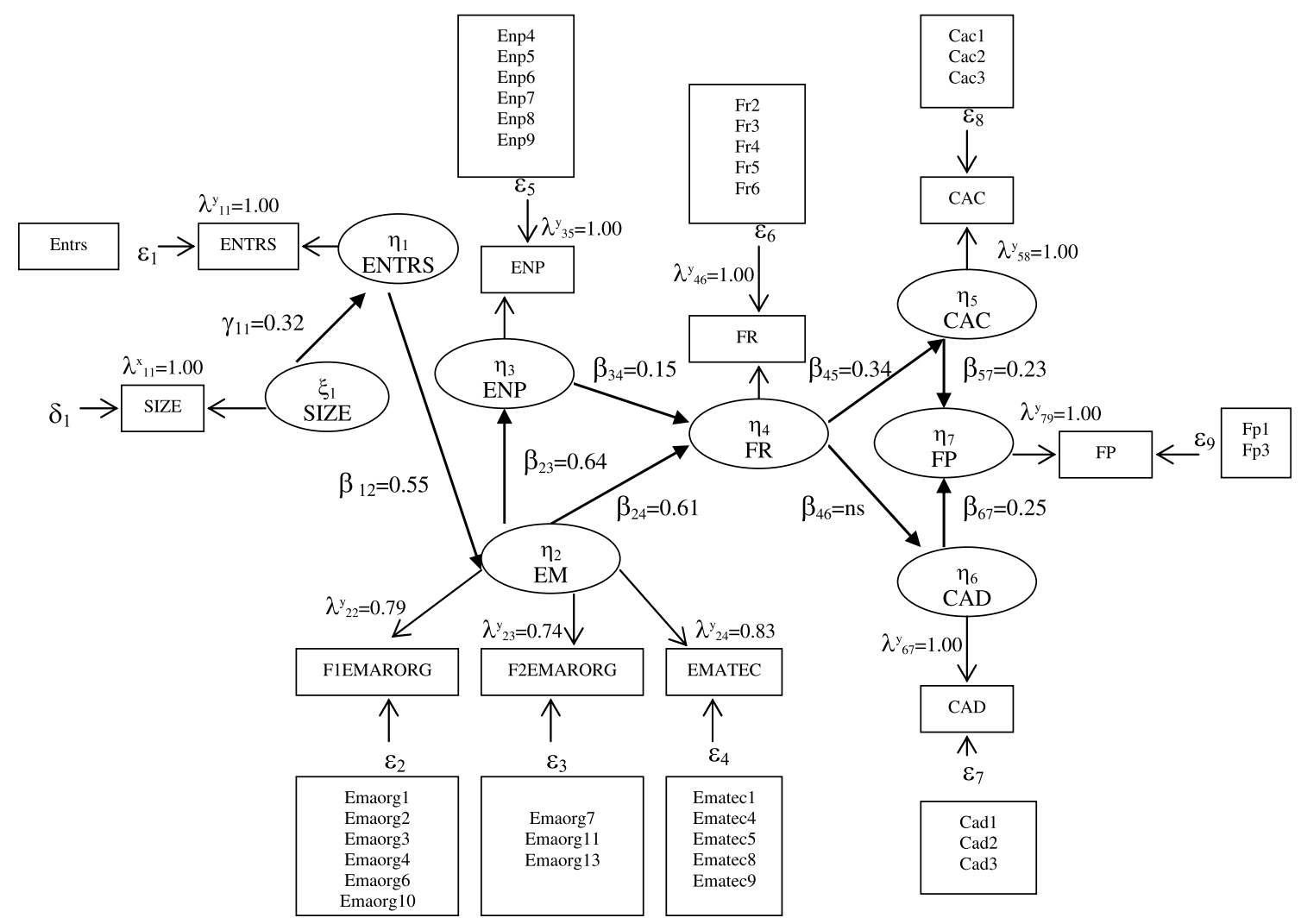

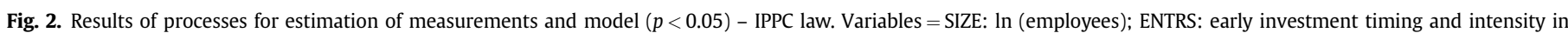

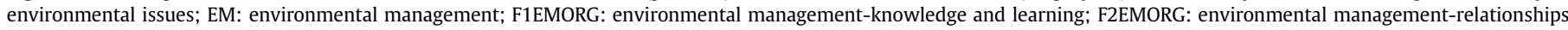

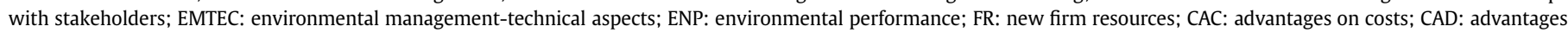
in differentiation; FP: financial performance.

between major variables were small, suggesting that adding additional paths would not significantly improve the fit. The statistically significant parameters (see Figs. 2 and 3) predicting that in both sectors, the relationship between the early investment time and intensity in environmental issues and the adoption of a proactive environmental management are positive and significant, thus supporting $\mathrm{H} 1$. We also find a statistically significant relationship between proactive environmental management and environmental performance improvement, which confirms H2. In the IPPC law sector, the findings reveal that firm resources mediate the positive relationships of proactive environmental management and environmental performance with cost competitive advantage, but not with differentiation, which supports $\mathrm{H} 3 \mathrm{a}$ and $\mathrm{H} 4 \mathrm{a}$, but not $\mathrm{H} 3 \mathrm{~b}$ and H4b. By contrast, we find that in the hotel sector, firm resources mediate the positive link between proactive environmental management and environmental performance with differentiation competitive advantage, but not with cost. This confirms $\mathrm{H} 3 \mathrm{~b}$ and $\mathrm{H} 4 \mathrm{~b}$ in the hotel sector, but not H3a and H4a. There is a significant, positive effect of cost and differentiation competitive advantage on financial performance in both sectors, thus confirming H5. Finally, in relation to size (control variable), it has only had a significant influence on the early investment time and intensity in environmental issues.

\section{Discussion and managerial implications}

In relation to the firm size (control variable), the results show that larger firms tend to integrate environmental practices into their organization earlier than smaller ones in the two sectors under study. Firm size may reflect the legitimacy principle or the extent to which the firm is visible to the public. This occurs because a large firm is either seen as a sector leader (Henriques and Sadorsky, 1996; Moore, 2001) or is likely to have a greater environmental risk (Chen et al., 2006). Nevertheless, size is not considered a determinant for the degree of proactivity in the development of environmental management. Aragón-Correa et al. (2008) also indicate in their study that size is a relevant but not a determining condition for developing the most proactive environmental management. Those authors suggest that small firms deal with scarcity of slack resources by means of specific organizational capabilities based on their unique strategic characteristics of shorter lines of communication and closer interaction, the presence of a founder's vision, flexibility in managing external relationships, and an entrepreneurial orientation.

There is a positive relationship between the early investment timing and intensity in environmental issues and the adoption of a proactive environmental management both in the hotel sector and in the firms affected by the IPPC law sector. These results coincide with the conclusions of Nehrt (1996) and Sarkis (2006), who indicate that early moving firms may be opting for more proactive environmental programs and practices that build on low emissions. The study has equally revealed that proactive environmental management leads to an improvement of environmental performance and firm performance in both sectors. Our findings coincide with those derived from previous research (e.g. Annandale et al., 2004; Melnyk et al., 2003; Zhu and Sarkis, 2004). In fact, Wagner (2005) also demonstrates that high levels of 


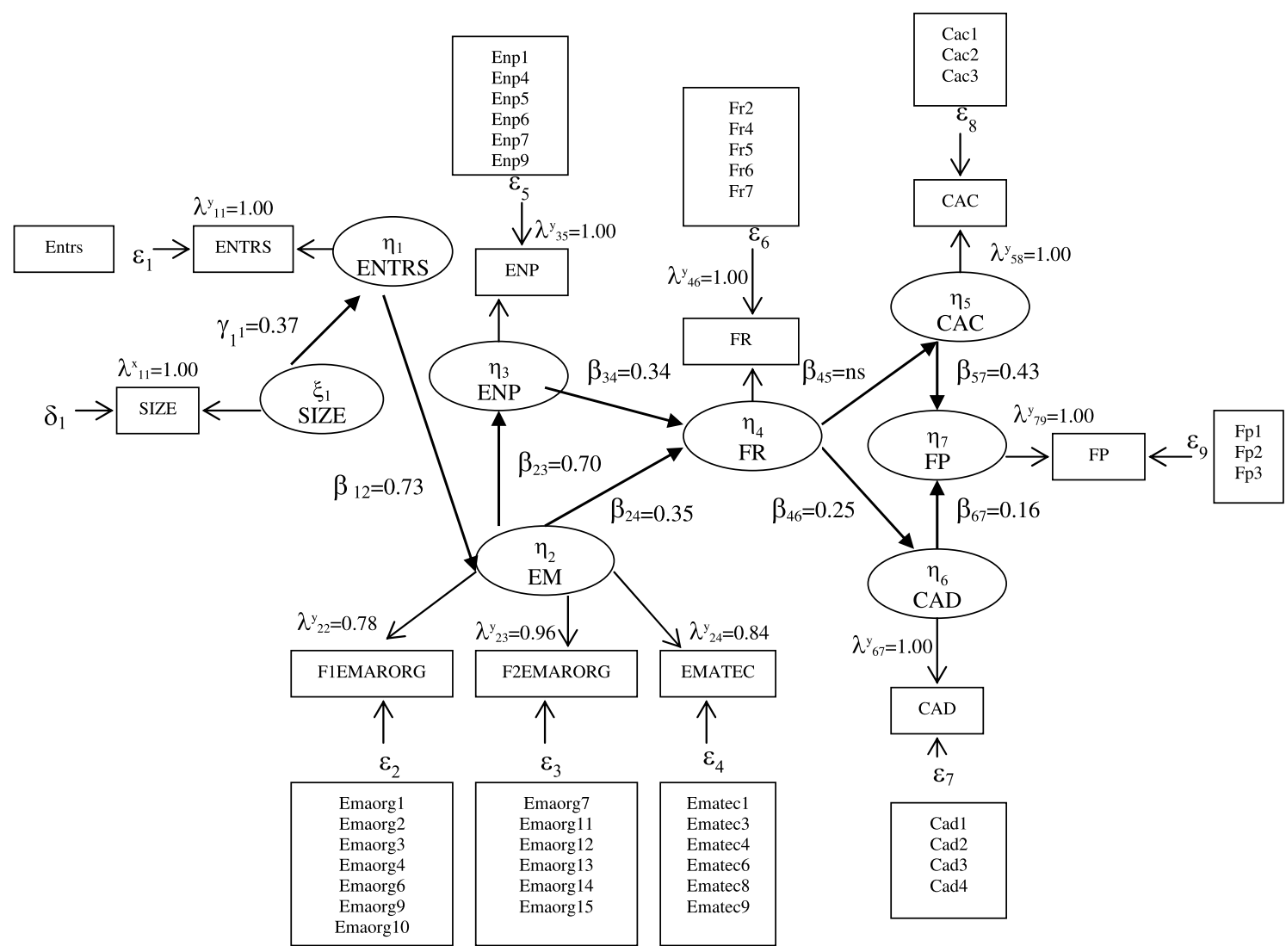

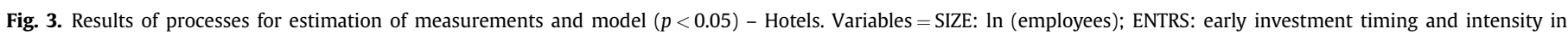

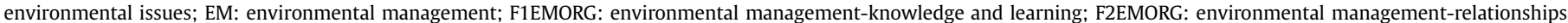

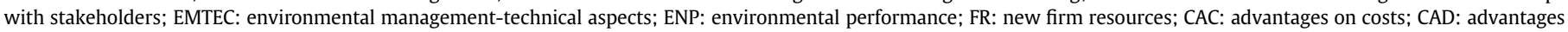
in differentiation; FP: financial performance.

environmental performance are only possible if a firm's environmental management has a proactive technological pollution orientation. Managers may have an interest in making an early environmental investment in proactive technologies because they believe that will give them a first-mover advantage to emerge as environmentally responsible organizations, reducing pollution and decreasing costs and improving their credibility and reputation.

As for the issues related to the mediating role of the resourcebased view in the relationship between environmental protection (proactive environmental management and environmental performance) and competitive advantage, we have confirmed the results that Galdeano-Gómez et al. (2008) and Sharma and Vredenburg (1998) found in their studies, investment in proactive pollution practices and environmental performance improvement contribute to the development of valuable capabilities which increase the competitiveness of the firm. However, the influence of these capabilities on the dimensions of competitive advantage is different according to the sector considered. Thus, in the hotel sector, environmental protection exerts a positive influence on the differentiation competitive advantage, while in the group of firms affected by the IPPC law the influence falls upon the cost competitive advantage. These findings show that managers in the hotel sector do not report any major changes in their cost position relative to key competitors, but firms investing in environmental improvements have to some extent gained a stronger reputation among customers. Although there have been advances in products and processes, the more significant effects seem to appear in marketing and image-building. The same results were reported in the study of Lindell and Karagozoglu (2001). Thus, managers in the hotel sector have excellent opportunities to establish a close link with customers and other stakeholders so as to develop loyalties and legitimacy based on ecological preservation, which in turn leads to differentiation competitive advantage (Sharma et al., 2007).

Table 4

Fit statistics for the structural equation model (full model).

\begin{tabular}{|c|c|c|c|c|c|c|c|c|c|}
\hline & $\chi^{2}$ Satorra-Bentler $(\mathrm{df})$ & RMSEA & 90\% Confidence & GFI & AGFI & NFI & NNFI & CFI & $\mathrm{NC}\left(\chi^{2} / \mathrm{df}\right)$ \\
\hline & $p$-Value & & interval for RMSEA & & & & & & \\
\hline Hotels & $\begin{array}{l}27.930(20) \\
0.111\end{array}$ & 0.040 & $(0.0 ; 0.073)$ & 0.973 & 0.926 & 0.972 & 0.973 & 0.988 & 1.39 \\
\hline IPPC law & $\begin{array}{l}21.524(20) \\
0.367\end{array}$ & 0.019 & $(0.0 ; 0.064)$ & 0.981 & 0.947 & 0.979 & 0.999 & 1.00 & 1.07 \\
\hline
\end{tabular}


In relation to the firms affected by the IPPC law, the findings suggest that when new environmental regulations come into play, firms which have already developed proactive environmental practices can take advantage of the complementarities in the process of adaptation and adapt to the new requirements in a more efficient way (Cañón-de-Francia et al., 2007). Indeed, the firm resources generated through proactive environmental management represent a supplementary asset that facilitates firm adaptation reducing the costs associated with the compliance with new environmental requirements (King and Lenox, 2000; Nakamura et al., 2001). Our findings are similar to those provided by Cañon-de-Francia et al. (2007), who argue that proactive technological environmental knowledge prepares a firm to adapt to the greater environmental demands derived from new legislation. Moreover, Christmann (2000) and Murty et al. (2006) also consider that most of the potential cost reductions depend on government regulations. The IPPC law implies the adoption of environmental practices that improve the production process, increasing its efficiency and reducing input and waste disposal costs, and the decisions related to these practices allow firms to gain competitive advantage through cost reductions (Fraj-Andrés et al., 2008). As for managers, our findings indicate the need to focus on the development of new organizational capabilities that can complement their willingness to respond to institutional forces developing proactive environmental strategies (Sharma et al., 2007).

Moreover, firms in the IPPC law sector have a less strong link with customers than with suppliers. Relationships with customers are practically uniform in all firms and there is little variation. Consequently, the chance of achieving differentiation competitive advantage through this group is limited. Conversely, joint problem solving with suppliers is more common, varies to a greater extent and, therefore, is more consequential in terms of achieving cost competitive advantage (McEvily and Marcus, 2005) through a better product quality and improved product features, or through a reduction of production costs (e.g. through packaging reductions or material substitution) and related processes, which can generate material savings or convert waste into valuable forms (Porter and Van der Linde, 1995). Managers can learn important lessons from the insight that different context factors, such as 'sector', have some influence on different competitive advantage (cost and differentiation). This finding supports a contingency view of sustainable management in which a fit of context and process becomes critical. Managers therefore need to identify which context factors are most relevant in the specific situation of their firm and focus on them, as they may make some patterns of integration more suitable than others to adopt (Wagner, 2007). Moreover, managers should take more advantage of the competitive opportunities resulting from proactive environmental management. Thus, managers of the IPPC law sector should undertake more actions to obtain a good reputation among customers, suppliers and authorities in order to achieve differentiation competitive advantage. Regarding managers in the hotel sector, they ought to exploit organizational capabilities such as continuous innovation, employee motivation and stakeholder involvement better in order to achieve cost competitive advantage.

Finally, cost and differentiation competitive advantage have a positive impact on financial performance both in the tourist sector and in the group of firms affected by the IPPC law. These findings are relevant because they show that the ultimate consequence of any competitive advantage derived from proactive environmental management is improved financial performance (González-Benito and González-Benito, 2005). This relationship also appears in the conclusions of Claver et al. (2007), Lindell and
Karagozoglu (2001) and Russo and Fouts (1997). Thus, our study is also important for managers because it reveals the opportunistic character of firms. After all, their ability to be proactive in relation to the environment comes from the possibility of gaining competitiveness and increasing their market share (Fraj-Andrés et al., 2008).

\section{Conclusions}

The debate about the relationship between environmental protection and firm performance has developed considerably in recent times. The lack of a solid theoretical foundation repeatedly emerges as the reason why the empirical works have not resulted in the convergence of knowledge (Aragón-Correa and Sharma, 2003; McWilliams and Siegel, 2001). Our contribution made in this study has been to state explicitly and test the path process between the different variables in our model. Although this path process is implicit in many previous works, we have offered a comprehensive whole picture. A better understanding of this process has helped to establish the connection between our first and last variables in our models. These variables have been analyzed in isolation in many previous works, but that "black box" approach has not supported an understanding of the connections and the reasons for potential differences. We have demonstrated that firms identified as earlier better environmental performers adopt more proactive environmental management practices. Moreover, this study demonstrates that firms can adopt a proactive environmental management which leads to better firm performance via firm resources. Our research also contributes to the resource-based view, indicating that these resources are relevant to obtain competitive advantage and financial performance. Finally, with this study, we clarify a relevant point in the literature by showing that the effect of environmental protection on firm performance is positive, though the mechanism is specific to the sector considered. Whereas cost competitive advantage influences financial performance in the IPPC law sector; the influence in the hotel sector relates to differentiation competitive advantage.

Finally, some limitations and future research lines should be noted. Firstly, since this research paper relies heavily on selfreported measurements provided by firm managers, future research works could add to the confidence place in the results reported here by replicating this study with more direct objective measurements of the theoretical constructs. Even so, in relation to environmental management, this alternate approach may also be inadequate since it may not fairly reflect a firm's overall environmental management due to its multidimensional nature. As Griffin and Mahon (1997) along with Johnson and Greening (1999) explicitly discuss in their studies, environmental management is a 'social performance' variable. Secondly, there are significant differences regarding the link between environmental protection and competitive advantage across sectors. The uniqueness of internal competencies or external pressures inherent in a sector, the degree of public visibility, the different configurations of stakeholders and their differing degrees of activism on particular issues are some of the possible reasons for these differences and suggest that the identification of the sector level circumstances should receive more attention. For this reason, we would like to suggest as a future line of research the possibility of integrating in our study some of these contingent variables (affecting our two samples to different extents) and make specific hypotheses as to how they affect our model. Moreover, it could be desirable to use some objective measurement of those variables. 


\section{Appendix}

Table A1. Factor loadings of exploratory principal components analysis results of environmental management - organizational aspects ${ }^{\mathrm{a}}$

\begin{tabular}{|c|c|c|c|c|}
\hline & \multicolumn{2}{|l|}{ IPPC law } & \multicolumn{2}{|l|}{ Hotels } \\
\hline & $\begin{array}{l}\text { Factor 1: } \\
\text { F1EMORG }\end{array}$ & $\begin{array}{l}\text { Factor2: } \\
\text { F2EMORG }\end{array}$ & $\begin{array}{l}\text { Factor 1: } \\
\text { F1EMORG }\end{array}$ & $\begin{array}{l}\text { Factor2: } \\
\text { F2EMORG }\end{array}$ \\
\hline $\begin{array}{l}\text { 1. The enterprise formally communicates its environmental policy and strategy to } \\
\text { all its employees }\end{array}$ & 0.874 & & 0.834 & \\
\hline $\begin{array}{l}\text { 2. The management team participates in and encourages environmental } \\
\text { management initiatives }\end{array}$ & 0.890 & & 0.853 & \\
\hline 3. The firm revises environmental and procedure manuals periodically & 0.913 & & 0.874 & \\
\hline $\begin{array}{l}\text { 4. The firm adapts or modifies organizational structures (the organizational chart } \\
\text { and the description of roles within the organization) if necessary in order to } \\
\text { facilitate environmental management }\end{array}$ & 0.805 & & 0.862 & \\
\hline $\begin{array}{l}\text { 5. The firm removes barriers to environmental communications, including } \\
\text { encouragement for employees to communicate directly with their managers or } \\
\text { with other firm employees }\end{array}$ & - & - & 0.714 & \\
\hline $\begin{array}{l}\text { 6. The employees have the environmental competencies required to develop their } \\
\text { professional activity }\end{array}$ & 0.733 & & 0.789 & \\
\hline $\begin{array}{l}\text { 7. When there is a wish to improve in some environmental aspect, the firm } \\
\text { establishes collaboration with other firms so that they can help to achieve the } \\
\text { improvement }\end{array}$ & & 0.683 & & 0.735 \\
\hline $\begin{array}{l}\text { 8. The firm gives support to experimentation with new methods with the aim of } \\
\text { identifying environmental improvement areas }\end{array}$ & - & - & - & - \\
\hline $\begin{array}{l}\text { 9. The firm establishes emergency procedures to respond to environmental } \\
\text { problems and accidents }\end{array}$ & - & - & 0.813 & \\
\hline $\begin{array}{l}\text { 10. The firm gives priority to the purchase of less harmful components and/or } \\
\text { products }\end{array}$ & 0.700 & & 0.822 & \\
\hline 11. The firm evaluates suppliers' environmental record & & 0.755 & & 0.746 \\
\hline 12. The firm uses a standardized system for the treatment of customer complaints & - & - & & 0.782 \\
\hline 13. The firm publishes an environmental report & & 0.843 & & 0.768 \\
\hline $\begin{array}{l}\text { 14. The firm sponsors environmental events and/or establishes collaboration with } \\
\text { ecologist organizations }\end{array}$ & - & - & & 0.802 \\
\hline $\begin{array}{l}\text { 15. The firm regularly provides information about environmental management to } \\
\text { suppliers, customers and institutions }\end{array}$ & - & - & & 0.610 \\
\hline KMO & 0.917 & & 0.953 & \\
\hline Bartlett's test of sphericity & $\chi^{2}=1300.862, \mathrm{df}=3$ & $p=0.001$ & $\chi^{2}=2618.424, \mathrm{df}=\mathrm{s}$ & $p=0.001$ \\
\hline Eigenvalue/\% of variance/Cronbach's alpha & $5.454 / 60.599 / 0.932$ & $1.090 / 72.712 / 0.736$ & $8.712 / 62.226 / 0.942$ & $1.239 / 69.191 / 0.887$ \\
\hline
\end{tabular}

a "Varimax" orthogonal rotation was performed.

\section{References}

Al-Tuwaijri, S., Christensen, T., Hughes, K., 2004. The relations among environmental disclosure, environmental performance, and economic performance: a simultaneous equations approach. Accounting, Organizations and Society 29, 447-471.

Annandale, D., Morrison-Saunders, A., Bouma, G., 2004. The impact of voluntary environmental protection instruments on company environmental performance. Business Strategy and the Environment 13,1-12.

Aragón-Correa, J., Hurtado-Torres, N., Sharma, S., García-Morales, V.J., 2008. Environmental strategy and performance in small firms: a resource-based perspective. Journal of Environmental Management 86, 88-103.

Aragón-Correa, J.A., Rubio-López, E.A., 2007. Proactive corporate environmental strategies: myths and misunderstandings. Long Range Planning 40, 357-381.

Aragón-Correa, J.A., Sharma, S., 2003. A contingent resource-based view of proactive corporate environmental strategy. Academy of Management Review 28, 71-88.

Armstrong, J., Overton, 1977. Estimating non-response bias in mail surveys. Journa of Marketing Research 14, 396-402.

Bagozzi, R., 1994. Structural Equation Model in Marketing Research, Basic Principles, Principles of Marketing Research. Blackwell Publishers, Oxford.

Barla, P., 2007. ISO 14001 certification and environmental performance in Quebec's pulp and paper industry. Journal of Environmental Economics and Management 53, 291-306.

Bono, J.E., Judge, T.A., 2003. Self-concordance at work: toward understanding the motivational effects of transformational leaders. Academy of Management Journal 46, 554-571.

Bowen, F.E., 2000. Environmental visibility: a trigger of green organizationa response? Business Strategy and the Environment 9, 92-107.

Brío, J.A., Fernández, E., Junquera, B., 2002. The role of the public administrations in the promotion of the environmental activity in Spanish industrial companies. Ecological Economics 40, 279-294.

Brío, J.A., Junquera, B., 2001. Level of implementation of the ISO 14001 standard in Spanish industrial companies. Eco-Management and Auditing 8, 193-199.

Cairncross, F., 1992. Costing the Earth. The Challenge for Governments, the Opportunities for Business. Harvard Business School Press, Boston, Massachusetts.
Cañón-de-Francia, J., Garcés-Ayerbe, C., Ramírez-Alesón, M., 2007. Are more innovative firms less vulnerable to new environmental regulation? Environmental and Resource Economics 36, 295-311.

Carmona-Moreno, E., Cespedes-Lorente, J., De Burgos-Jiménez, J., 2004. Environmental strategies in Spanish hotels: contextual factors and performance. The Service Industries Journal 24, 101-130.

Chan, E.S.W., Wong, S.C.K., 2006. Motivations for ISO 14001 in the hotel industry. Tourism Management 27, 481-492.

Chen, Y.-S., Lai, S.-B., Wen, C.-T., 2006. The influence of green innovation performance on corporate advantage in Taiwan. Journal of Business Ethics 67, 331-339.

Christmann, P., 2000. Effects of "best practices" of environmental management on cost advantage: the role of complementary assets. Academy of Management Journal 43, 663-680.

Claver, E., López, M.D., Molina, J.F., Tarí, J.J., 2007. Environmental management and firm performance: a case study. Journal of Environmental Management 84, 606-619.

Cramer, J., 1998. Environmental management: from 'fit' to 'stretch'. Business Strategy and the Environment 7, 162-172.

Dowell, G., Stuart, H., Bernard, Y., 2000. Do corporate environmental standards create or destroy market value? Management Science 46, 1059-1074.

Eurostat (Statistical Office of the European Communities), 2009. Number of persons employed in services in the EU-27 by sector. Published online: http://epp. eurostat.ec.europa.eu/portal/page?_pageid=1996,45323734\&_dad=portal\& schema $=$ PORTAL\&screen $=$ welcomeref\&open $=/$ \&product $=$ REF $\_$TB services\&depth $=2$

Fraj-Andrés, E., Martínez-Salinas, E., Matute-Vallejo, J., 2008. Factors affecting corporate environmental strategy in Spanish industrial firms. Business Strategy and the Environment doi:10.1002/bse0.611.

Galdeano-Gómez, E., Céspedes-Lorente, J., Martínez-del-Río, J., 2008. Environmental performance and spillover effects on productivity: evidence from horticultural firms. Journal of Environmental Management 88, 1552-1561.

Gamble, G.O., Hsu, K., Kite, D., Radtke, R.D., 1995. Environmental disclosures in annual reports and 10ks: an examination. Accounting Horizons 9, 34-54.

Ghemawat, P., 1986. Sustainable advantage. Harvard Business Review 64, 53-58.

Gilbert, J.T., Birnbaum-More, P.H., 1996. Innovation timing advantages: from economic theory to strategic application. Journal of Engineering and Technology Management (JET-M) 12, 245-266. 
González-Benito, J., González-Benito, O., 2005. Environmental proactivity and business performance: an empirical analysis. Omega 33,1-15.

Gray, R., Javad, M., Power, D.M., Singlair, C.D., 2001. Social and environmental disclosure and corporate characteristics: a research note and extension. Journal of Business Finance \& Accounting 28, 327-356.

Gribbons, B.C., Hocevar, D., 1998. Levels of aggregation in higher level confirmatory factor analysis: application for academic self-concept. Structural Equation Modelling 4, 377-390.

Griffin, J.J., Mahon, J.F., 1997. The corporate social performance and corporate financial performance debate: twenty-five years of incomparable research. Business and Society 36, 5-31.

Hart, S., 1995. A natural-resource-based view of the firm. Academy of Management Journal 20, 986-1014

Hart, S.L., Ahuja, G., 1996. Does it pay to be green? An empirical examination of the relationship between emission reduction and firm performance. Business Strategy and the Environment 5, 30-37.

Henri, J.-F., Journeault, M., 2008. Environmental performance indicators: an empirical study of Canadian manufacturing firms. Journal of Environmental Management 87, 165-176.

Henriques, I., Sadorsky, P., 1996. The determinants of an environmentally responsive firm: an empirical approach. Journal of Environmental Economics and Management 30, 381-395.

Hutchinson, C., 1996. Integrating environment policy with business strategy. Long Range Planning 29, 11-23.

INE (Spanish Statistics Institute), 2009. Cuenta Satélite del Turismo de España. Base 2000. Serie Contable 2000-2007. Published online: http://www.ine.es/jaxi/ menu.do?type $=$ pcaxis \&path $=/$ t35/p011/2007/\&file $=$ pcaxis

Jaffe, A., Peterson, S., Portney, P., Stavins, R., 1995. Environmental regulation and the competitiveness of U.S. manufacturing: what does the evidence tell us? Journal of Economic Literature 33, 132-163.

Johnson, R.A., Greening, D.W., 1999. The effects of corporate governance and institutional ownership types on corporate social performance. Academy of Management Journal 42, 564-576.

Jöreskog, K.G., 1971. Simultaneous factor analysis in several populations. Psychometrica 57, 409-426.

Jöreskog, K.G., Sorbom, D., 1993. LISREL 8. Structural Equation Modelling with the SIMPLIS Command Language. Scientific Software, Hillsdale.

Judge, W., Douglas, T., 1998. Performance implications of incorporating natural environmental issues into the strategic planning process: an empirical assessment. Journal of Management Studies 35, 241-262.

Judge, W.Q., Elenkov, D., 2005. Organizational capacity for change and environmental performance: an empirical assessment of Bulgarian firms. Journal of Business Research 58, 893-901.

Karagozoglu, N., Lindell, M., 2000. Environmental management: testing the winwin model. Journal of Environmental Planning and Management 43, 817-829.

King, A., Lenox, M., 2000. Industry self-regulation without sanctions: the chemical industry's responsible care program. The Academy of Management Journal 43, 698-716.

King, A., Lenox, M., 2002. Exploring the locus of profitable pollution reduction. Management Science 48, 289-299.

Kirk, D., 1995. Environmental management in hotels. International Journal of Contemporary Hospitality Management 7, 3-8.

Klassen, R.D., McLaughlin, C., 1996. The impact of environmental management on firm performance. Management Science 42, 1199-1214.

Klassen, R.D., Whybark, D.C., 1999. The impact of environmental technologies on manufacturing performance. Academy of Management Journal 42, 599-615.

Konar, S., Cohen, M.A., 2001. Does the market value environmental performance? The Review of Economics and Statistics 83, 281-289.

Landis, R.S., Bela, D.J., Tesluk, P.E., 2000. A comparison of approaches to composite measures in structural equation models. Organizational Research Methods 3, 186-207.

Lankoski, L., 2008. Corporate responsibility activities and economic performance: a theory of why and how they are connected. Business Strategy and the Environment 17, 536-547.

Lindell, M., Karagozoglu, N., 2001. Corporate environmental behaviour a comparison between Nordic and US firms. Business Strategy and the Environment $10,38-52$.

Link, S., Naveh, E., 2006. Standardization and discretion: does the environmental standard ISO 14001 lead to performance benefits? IEEE Transactions on Engineering Management 53, 508-519.

López-Gamero, M.D., Claver-Cortés, E., Molina-Azorín, J.F., 2008. Complementary resources and capabilities for an ethical and environmental management: a qual/quan study. Journal of Business Ethics 82, 701-732.

McEvily, B., Marcus, A., 2005. Embedded ties and the acquisition of competitive capabilities. Strategic Management Journal 26, 1033-1055.

McWilliams, A., Siegel, D., 2001. Corporate social responsibility: a theory of the firm perspective. Academy of Management Review 26, 117-127.

Melnyk, S., Sroufe, R., Calantone, R., 2003. Assessing the impact of environmental management systems on corporate and environmental performance. Journal of Operations Management 21, 329-351.

Menguc, B., Ozanne, L., 2005. Challenges of the "green imperative": a natural resource-based approach to the environmental orientation-business performance relationship. Journal of Business Research 58, 430-438.

Miles, M.P., Covin, J.G., 2000. Environmental marketing: a source of reputational competitive, and financial advantage. Journal of Business Ethics 23, 299-311.
Moore, G., 2001. Corporate social and financial performance: an investigation in the U.K. supermarket industry. Journal of Business Ethics 34, 299-315.

Murty, M.N., Kumar, S., Paul, M., 2006. Environmental regulation, productive efficiency and cost of pollution abatement: a case study of the sugar industry in India. Journal of Environmental Management 79, 1-9.

Nakamura, M., Takahashi, T., Vertinsky, I., 2001. Why Japanese firms choose to certify: a study of managerial responses to environmental issues. Journal of Environmental Economics and Management 42, 23-52.

Nakao, Y., Amano, A., Matsumura, K., Genba, K., Nakano, M., 2007. Relationship between environmental performance and financial performance: an empirical analysis of Japanese corporations. Business Strategy and the Environment 16, 106-118.

Nehrt, C., 1996. Timing and intensity effects of environmental investments. Strategic Management Journal 17, 535-547.

Porter, M., Van der Linde, C., 1995. Toward a new conception of the environmentcompetitiveness relationship. Journal of Economic Perspectives 9, 97-118.

Ramus, C.A., Montiel, I., 2005. When are corporate environmental policies a form of greenwashing? Business and Society 44, 377-414.

Roy, R., 1999. Designing and marketing greener products: the Hoover case. In: Charter, M., Polonsky, M.F. (Eds.), Greener Marketing: A Global Perspective to Greening Marketing Practice. Greenleaf, Sheffield, pp. 126-142.

Russo, M.V., Fouts, P.A., 1997. A resource-based perspective on corporate environmental performance and profitability. Academy of Management Journal 40, 534-559.

Sarkis, J., 2006. The adoption of environmental and risk management practices: relationships to environmental performance. Annual Operational Research 145, 367-381.

Satorra, A., Bentler, P.M., 1994. Corrections to test statistics and standard errors in covariance structure analysis. In: Von Eye, A., Clogg, C.C. (Eds.), Latent Variables Analysis: Applications for Developmental Research. Sage, Thousand Oaks.

Schaltegger, S., Figge, F., 2000. Environmental shareholder value: economic success with corporate environmental management. Eco-Management and Auditing 7 , 29-42.

Schaltegger, S., Synnestvedt, T., 2002. The link between 'green' and economic success: environmental management as the crucial trigger between environmental and economic performance. Journal of Environmental Management 65, 339-346

Sharma, S., Aragón-Correa, J.A., Rueda-Manzanares, A., 2007. The contingent influence of organizational capabilities on proactive environmental strategy in the service sector: an analysis of North American and European ski resorts. Canadian Journal of Administrative Sciences 24, 268-283.

Sharma, S., Vredenburg, H., 1998. Proactive corporate environmental strategy and the development of competitively valuable organizational capabilities. Strategic Management Journal 19, 729-753.

Shih, K.-H., Chen, H.-J., Chen, J.C.H., 2006. Assessment of sustainable development and knowledge of environmental management: internal auditors' perspectives. Industrial Management \& Data 106, 896-909.

Shrivastava, P., 1995. Environmental technologies and competitive advantage Strategic Management Journal 16, 183-200.

Song, X.M., Di Benedetto, C.A., Zhao, Y.L., 1999. Pioneering advantages in manufacturing and service industries: empirical evidence from nine countries. Strategic Management Journal 20, 811-836.

Stanwick, P.A., Stanwick, S.D., 1998. The relationship between corporate social performance, and organizational size, financial performance, and environmental performance: an empirical examination. Journal of Business Ethics 17 195-204.

Szymanski, M., Tiwari, P., 2004. ISO 14001 and the reduction of toxic emissions Policy Reform 7, 31-42.

Trung, D., Kumar, S., 2005. Resource use and waste management in Vietnam hotel industry. Journal of Cleaner Production 13, 109-116.

Wagner, M., 2005. How to reconcile environmental and economic performance to improve corporate sustainability: corporate environmental strategies in the European paper industry. Journal of Environmental Management 76, 105-118.

Wagner, M., 2007. Innovation and competitive advantages from the integration of strategic aspects with social and environmental management in European firms. Business Strategy and the Environment doi:10.1002/bse0.585.

Wagner, M., Schaltegger, S., 2004. The effect of corporate environmental strategy choice and environmental performance on competitiveness and economic performance: an empirical study of EU manufacturing. European Management Journal 22, 557-572.

Wagner, M., Van Phu, N., Azomahou, T., Wehrmeyer, W., 2002. The relationship between the environmental and economic performance of firms: an empirical analysis of the European paper industry. Corporate Social Responsibility and Environmental Management 9, 133-146.

Wahba, H., 2008. Does the market value corporate environmental responsibility? An empirical examination. Corporate Social Responsibility and Environmenta Management 15, 89-99.

Walley, N., Whitehead, B., 1994. It's not easy being green. Harvard Business Review 72, 46-52.

Watson, K., Klingenberg, B., Polito, T., Geurts, T., 2004. Impact of environmental management system implementation on financial performance. Management of Environmental Quality 15, 622-628.

Zhu, Q., Sarkis, J., 2004. Relationships between operational practices and performance among early adopters of green supply chain management practices in Chinese manufacturing enterprises. Journal of Operations Management 22, 265-289. 